
\title{
$\begin{array}{ll}\text { Research Square } & \begin{array}{l}\text { Preprints are preliminary reports that have not undergone peer review. } \\ \text { They should not be considered conclusive, used to inform clinical practice, } \\ \text { or referenced by the media as validated information. }\end{array}\end{array}$
}

\section{Faith-Based Lifestyle Intervention Program Reduces Metabolic Syndrome in a High-risk Population}

\section{Ronda Rose Davis}

Sahmyook University

Hyo-Jeong Hwang

Sahmyook University

\section{Easton A. Reid}

Africabio Enterprises Inc.

Joo Youn Chung

National Tobacco Control Center

Andrea Leah Scott

Allegheny East Conference of SDA Pine Forge

Helen Powell-Stoddart

Pain 2 Wellness Healthcare

\section{Tae-Hwan Jung}

Shamyook University

Kyoung-Sik Han ( $\sim$ kshan@syu.ac.kr)

Sahmyook University https://orcid.org/0000-0001-8121-7348

\section{Research}

Keywords: Faith-based lifestyle, Metabolic syndrome, Plant-based nutrition, Physical activity, Health education

Posted Date: July 2nd, 2020

DOI: https://doi.org/10.21203/rs.3.rs-38255/v1

License: @ (i) This work is licensed under a Creative Commons Attribution 4.0 International License. Read Full License 


\section{Abstract}

Introduction: The aim of this study was to investigate the effects of a two-week lifestyle intervention on risk factors contributing to metabolic syndrome that incorporated a natural environment with spiritual motivation, plant-based nutrition, personalized physical activity, and health education.

Methods: The demographic population included forty-two middle-aged and aged participants of African-American or AfroCaribbean/Other Afro-descent, considered "high-risk" according to clinical cardiometabolic risk indicators.

Results: Based on the stratified analysis, $59.5 \%$ and $40.5 \%$ were of African-American and Afro-Caribbean/Other Afro-descent respectively, with a mean age of $59.23 \pm 11.24$ years. The paired t-test indicated that plasma concentrations of glucose $(P=$ $0.043)$ and triglyceride $(P=0.002)$ post-intervention reduced compared to pre-intervention baselines. In female participants, blood HDL cholesterol concentrations significantly $(P<0.0001)$ increased compared to pre-intervention values.

Conclusion: This research suggests that the Fit 4 You Retreat lifestyle intervention program significantly reduced cardiometabolic vulnerability in this high-risk middle-aged and aged population.

\section{Introduction}

Metabolic syndrome has been rapidly increasing throughout the world, with lifestyle being identified as the most significant risk contributing to this condition [1, 2]. Metabolic syndrome refers to the co-occurrence of several known cardiovascular risk factors, including insulin resistance, obesity, atherogenic dyslipidemia and hypertension [3]. This increase is associated with the global epidemic of obesity and diabetes [4].

Owing to rapid transitions toward high energy intake and sedentary lifestyle in the past few decades, the metabolic syndrome has become a major health challenge globally. The grand problem is that at intervention completion, high-risk participants often face the challenges of compliance and sustainability. Although people are constantly exposed to an abundance of information regarding the benefits of healthy lifestyles, Americans continue to struggle with obesity, physical inactivity, and inadequate nutrition [5].

Additional studies revealed that certain economically disadvantaged ethnic minorities and elderly populations were at significantly higher risk for cardiovascular disease (CVD) due to unhealthy lifestyles. In addition, minority communities were reported to have greater than equal or double the risk for CVD. Compared to other populations, minorities were also at greater risk for other conditions such as hypertension, diabetes, and dyslipidemia with increased potential for obesity, poor nutrition and sedentary lifestyles [5-7].

There are specific determinants used to diagnose the metabolic syndrome. In this study, we used the National Cholesterol Education Program's Adult Treatment Panel III (NCEP: ATP III)'s definition to identify the clinical indicators: high-density lipoprotein cholesterol (HDL-C), central obesity, hypertension, high fasting glucose and high triglyceride (TG) values [8,9]. Study subjects were diagnosed as having the metabolic syndrome if he or she had three or more of the following criteria: 1) waist circumference $\geq 90 \mathrm{~cm}$ for men and $\geq 80 \mathrm{~cm}$ for women; 2) TG $\geq 150 \mathrm{mg} / \mathrm{dL}$; 3) HDL-C $<40 \mathrm{mg} / \mathrm{dL}$ for men and < $50 \mathrm{mg} / \mathrm{dL}$ for women; 4) blood pressure $\geq 130 / 85 \mathrm{mmHg}$; and 5) fasting glucose $\geq 100 \mathrm{mg} / \mathrm{dL}$ [3]. Clinicians prefer simple guidelines with which to assess patients and improve management, and the generally accepted definition for metabolic syndrome prescribed by the NCEP: ATP-III definition is simple to use and is the preferred standard [6].

People at high risk for metabolic syndrome should manage dietary factors in conjunction with exercise. The basic principle for nutritional management is that the intake of saturated fat, trans-fats and cholesterol is low, the consumption of simple sugars is reduced, and the consumption of fruits, vegetables and whole grains is increased, resulting in positive outcomes which have been demonstrated through various studies [10,11]. 
In the current literature, research findings indicated that in the United States, there have been persistent racial and ethnic disparities in CVD morbidity and mortality. National efforts have given attention to reducing these disparities; but the cause of long-term health disparities remains unknown [12]. A number of community-based interventions have consistently emerged in research literature with moderate success. Considering a different approach, this intervention incorporated cultural and religious sensitivity in order to design a faith-based component as one of the constructs for lifestyle health success. Numerous commercially designed lifestyle programs have been conducted in minority and ethnic-church congregations but these programs typically do not use faith as a motivating factor for lifestyle health behavioral change. Therefore, this study was designed incorporating faith engagement as a key fundamental motivation of lifestyle change.

Health behavior research in the African-American/Afro-Caribbean community suggests a strong correlation between health and religious beliefs. A qualitative study conducted with members of an African-American church community in South Carolina, identified faith as an enabler to increase physical activity [13]. Within the African-American/Afro-Caribbean community faith is an essential part of the culture, therefore programs that address this component have a greater potential for a positive impact on behavioral change [14]. Extensive research within this cultural context indicates that faith-based initiatives have typically utilized trained lay personnel or health professionals to promote health risk prevention in the church/community-based setting.

The objective of this study was to examine the validity of the Fit 4 You Retreat Lifestyle Intervention program. This intervention integrates the unique elements of the African-American/Afro-Caribbean culture like faith and gospel music with health principles such as plant-based nutrition, physical activity, and health education to enhance compliance and reduce risk factors associated with metabolic syndrome.

\section{Methods}

\section{Design}

This multi-faceted, two-week intervention incorporates spiritual motivation (prayer, meditation, and music), plant-based nutrition, a natural environment, personalized physical activity, and health education to reduce cardiometabolic risk factors. This paper evaluates a culturally sensitive, faith-based lifestyle intervention designed to reduce indicators for metabolic syndrome and addresses the gap in the literature regarding the unique needs of the African-American/Afro-Caribbean community. This study was approved by Sahmyook University's institutional review board (SYUIRB\# 2011-015) and conducted during the two-week summer session of the Fit 4 You Retreat, July 8-22, 2012.

\section{Participants}

The Fit 4 You Retreat is located on the campgrounds of the Allegheny East Conference of Seventh Day Adventists in Boyertown, Pennsylvania, USA. Sixty-seven individuals started the program but, some were only "one-week" participants who did not complete the entire two-week retreat and were therefore excluded, yielding a final count of forty-two individuals.

\section{Procedure and measures}

The objective of this lifestyle intervention was to promote physical, mental, social, and spiritual wellness. Attendees' meals were plant-based (vegan). Participants followed a daily schedule of physical activity, seminars, behavioral health training, and faith-based activities to promote holistic health. In order to achieve the most comprehensive level of lifestyle training, health education instruction introduced the Fit 4 You Retreat concept of lifestyle modification. In order to establish baseline values, a comprehensive metabolic panel assessment was taken which included fasting lipid and glucose blood profiles.

Participants were required to fast after the evening meal served at 6 PM for supper on the day of arrival (sunday) until baseline blood levels were drawn the following morning at $6 \mathrm{AM}$. During the first week, consultation appointments were scheduled, and initial assessments were reviewed by an on-site medical professional. The medical and fitness teams 
reviewed performance and clinical parameters to determine participant placement in one of the fitness training groups that were arranged by activity level.

A variety of health seminars and educational lectures were provided during the morning sessions throughout the week. Professionals from both the health and medical disciplines provided a wide variety of lectures and presentations featuring topics like: functional exercise, depression and anxiety, cancer prevention, heart disease, diabetes prevention, and nutrition.

Retreat participants were encouraged to research and present (as a team or individually) one of the principles of lifestyle health during the lunch hour. The Fit 4 You Retreat concept of lifestyle change was taught throughout the program. Faithbased devotional sessions were presented during breakfast and after supper. Additional activities included a variety of therapeutic modalities like art, music, and massage therapy.

The daily menu had an average of 887 calories (fat $23.4 \mathrm{~g}$, total carbohydrates $149.4 \mathrm{~g}$, protein $35.45 \mathrm{~g}$, dietary fiber $39.6 \mathrm{~g}$, sodium $1,918 \mathrm{mg}$ ) per meal. Breakfast, lunch and a light supper were served daily at five-hour intervals prepared by the kitchen staff under the supervision of certified vegan/vegetarian chefs (Table 1). Spirituality is a key component of the Fit 4 You Retreat concept as represented in; Faith \& fitness, Intentional improvement and Time sensitive transformation for Your true value, Outstanding opportunities for an abundant lifestyle, and Unlimited capacity for change were emphasized throughout the program. Participants were encouraged to consider their lifestyle habits associated with their faith and commitment to God as the foundation for motivation and discipline. The program culminated with an evening banquet to model healthy ways to celebrate and enjoy special occasions. 
Table 1

Fit 4 U camp menu

\begin{tabular}{|c|c|c|c|c|c|c|c|}
\hline Time & Sunday & Monday & Tuesday & Wednesday & Thursday & Friday & Saturday \\
\hline Breakfast & $\begin{array}{l}\text { Oat Pancakes } \\
\text { with Fruit } \\
\text { Sauce } \\
\text { Breakfast } \\
\text { Beans } \\
\text { Almonds } \\
\text { Ground } \\
\text { Flaxseed } \\
\text { Soy/Almond } \\
\text { Milk }\end{array}$ & $\begin{array}{l}\text { Broccoli } \\
\text { Tofu } \\
\text { Scramble } \\
\text { Breakfast } \\
\text { Sweet } \\
\text { Potato } \\
\text { Hash with } \\
\text { Peppers } \\
\text { Fruit } \\
\text { Pecans } \\
\text { Ground } \\
\text { Flaxseed }\end{array}$ & $\begin{array}{l}\text { Breakfast } \\
\text { Bread or } \\
\text { Quinoa } \\
\text { Pudding } \\
\text { Breakfast } \\
\text { Beans Fruit } \\
\text { Almonds } \\
\text { Ground } \\
\text { Flaxseed } \\
\text { Soy/Almond } \\
\text { Milk }\end{array}$ & $\begin{array}{l}\text { Polenta } \\
\text { with Fruit } \\
\text { Sauce } \\
\text { Breakfast } \\
\text { Beans } \\
\text { Fruit } \\
\text { Walnuts } \\
\text { Ground } \\
\text { Flaxseed }\end{array}$ & $\begin{array}{l}\text { Apple } \\
\text { Supreme } \\
\text { Breakfast } \\
\text { Beans Toast } \\
\text { Almond } \\
\text { Butter } \\
\text { Ground } \\
\text { Flaxseed } \\
\text { Soy/Almond } \\
\text { Milk }\end{array}$ & $\begin{array}{l}\text { Sweet } \\
\text { Potato } \\
\text { and Black } \\
\text { Bean } \\
\text { Burrito } \\
\text { Pico } \\
\text { Fresca } \\
\text { fruit } \\
\text { Almonds } \\
\text { Ground } \\
\text { Flaxseed }\end{array}$ & $\begin{array}{l}\text { Granola } \\
\text { Breakfast } \\
\text { Beans Fruit } \\
\text { Ground } \\
\text { Flaxseed } \\
\text { Soy/Almond } \\
\text { Milk }\end{array}$ \\
\hline Lunch & $\begin{array}{l}\text { Oat Burgers } \\
\text { Chick } \\
\text { Pea/Lentil } \\
\text { Patties } \\
\text { Potato Salad } \\
\text { Cole Slaw- } \\
\text { Broccoli salad } \\
\text { Spinach Salad } \\
\text { Corn } \\
\text { Baked Beans } \\
\text { CondimeMelon } \\
\text { Slices }\end{array}$ & $\begin{array}{l}\text { Rice Stack } \\
\text { (Rice, } \\
\text { Lentils, } \\
\text { Lettuce, } \\
\text { Tomatoes, } \\
\text { Cucumbers, } \\
\text { Scallions, } \\
\text { Peppers, } \\
\text { Sour } \\
\text { Cream, } \\
\text { Cashew } \\
\text { Cheese) } \\
\text { Salad Bar }\end{array}$ & $\begin{array}{l}\text { Spud } \\
\text { Mountain } \\
\text { Spinach } \\
\text { Cauliflower, } \\
\text { Yellow } \\
\text { Squash, } \\
\text { Carrots and } \\
\text { Peas } \\
\text { Salad Bar }\end{array}$ & $\begin{array}{l}\text { Ratatouille } \\
\text { with } \\
\text { Chick Peas } \\
\text { Whole } \\
\text { Grain } \\
\text { Pasta } \\
\text { Green } \\
\text { Beans } \\
\text { Salad Bar }\end{array}$ & $\begin{array}{l}\text { Vegetable } \\
\text { Stir Fry } \\
\text { over Brown } \\
\text { Rice } \\
\text { Bok Choy \& } \\
\text { Cabbage } \\
\text { Salad Bar }\end{array}$ & $\begin{array}{l}\text { Chili } \\
\text { (Pinto, } \\
\text { Garbanzo, } \\
\text { \&Kidney) } \\
\text { Broccoli \& } \\
\text { Carrots } \\
\text { Yellow } \\
\text { Squash } \\
\text { Corny } \\
\text { Cornbread } \\
\text { Salad Bar }\end{array}$ & $\begin{array}{l}\text { Meatloaf } \\
\text { Gingered } \\
\text { Carrots } \\
\text { Kale } \\
\text { Roasted } \\
\text { Beets } \\
\text { Salad Bar }\end{array}$ \\
\hline Dinner & $\begin{array}{l}\text { Summer } \\
\text { Vegetable } \\
\text { Soup }\end{array}$ & $\begin{array}{l}\text { Cream of } \\
\text { Asparagus } \\
\text { Soup } \\
\text { Salad }\end{array}$ & $\begin{array}{l}\text { White Bean } \\
\text { and Kale } \\
\text { Soup } \\
\text { Salad }\end{array}$ & $\begin{array}{l}\text { Mixed } \\
\text { Green } \\
\text { Salad } \\
\text { Fruit }\end{array}$ & $\begin{array}{l}\text { Lemony } \\
\text { Lentil } \\
\text { Vegetable } \\
\text { Stew } \\
\text { Salad }\end{array}$ & $\begin{array}{l}\text { Tropical } \\
\text { Fruit } \\
\text { Salad on } \\
\text { Lettuce } \\
\text { Greens }\end{array}$ & $\begin{array}{l}\text { Popcorn } \\
\text { Smoothies }\end{array}$ \\
\hline
\end{tabular}

\section{Blood sampling and determination of general serum biochemical variables}

Laboratory blood work was outsourced (Quest Diagnostics Inc.). Blood samples were collected in the fasting state and immediately centrifuged at $3,000 \mathrm{rpm}$ for 15 minutes at $4{ }^{\circ} \mathrm{C}$. Serum specimens were frozen at $-80{ }^{\circ} \mathrm{C}$ until further analysis. Serum TG and total cholesterol levels were measured by the enzymatic-colorimetric method, HDL-C and low-density lipoprotein cholesterol levels were determined via the homogeneous enzymatic-colorimetry method. Fasting blood glucose levels were measured using a Glucocard X-meter (Arkray, Inc., Kyoto, Japan).

\section{Data analysis}

Data were analyzed using the Statistical Package for the SAS software (Version 9.4; SAS Institute, Cary, NC) for Windows. Demographic data were expressed as proportions for categorical variables. Values were expressed as mean values \pm standard deviation and N (\%). The baseline characteristics, in Fit 4 You Retreat groups were compared using Chi-square tests. Paired t-test was used for comparison of the measurements (blood profile, metabolic syndrome index) prior to and after the intervention. All statistical tests were two-tailed, and a $P$-value $<0.05$ was considered significant. 


\section{Results}

The socio-demographic profile for qualified participants is shown in Table 2. Study participants consisted of 42 individuals ( 37 women and 5 men) from various regions of the United States and the Caribbean. To examine the effect of the interventions on individual cardiometabolic components, life-table analyses were performed.

Table 2

Baseline characteristics of the participants $(n=42)$

\begin{tabular}{|c|c|}
\hline Variables & Number (\%) \\
\hline \multicolumn{2}{|l|}{ Age (Years) } \\
\hline$<55$ & $11(26.2)$ \\
\hline $55-65$ & $20(47.6)$ \\
\hline$>65$ & $11(26.2)$ \\
\hline \multicolumn{2}{|l|}{ Gender } \\
\hline Female & $38(90.5)$ \\
\hline Male & $4(9.5)$ \\
\hline \multicolumn{2}{|l|}{ Race/Ethnicity } \\
\hline African-American & $23(59.5)$ \\
\hline Afro-Caribbean/Other Afro-Descent & $19(40.5)$ \\
\hline \multicolumn{2}{|l|}{ Marital Status } \\
\hline Single & $7(16.7)$ \\
\hline Married & $22(52.4)$ \\
\hline Divorced/Widowed/Living with Partner/Unknown & $13(31.0)$ \\
\hline \multicolumn{2}{|l|}{ Income Per Month (USD\$) } \\
\hline$\leq 2,999$ & $18(42.9)$ \\
\hline $3,000-4,999$ & $10(23.8)$ \\
\hline$\geq 5,000$ & $14(33.3)$ \\
\hline \multicolumn{2}{|l|}{ Educational Level } \\
\hline College/High school/Unknown & $21(50.0)$ \\
\hline Graduate School/Post Graduate Study & $21(50.0)$ \\
\hline \multicolumn{2}{|l|}{ Occupation } \\
\hline Working Professional & $22(52.0)$ \\
\hline Retired/Student/Home Maker/Unknown & $20(48.0)$ \\
\hline \multicolumn{2}{|l|}{ Religious Affiliation } \\
\hline Christian-Protestant/Catholic/Unknown & $18(42.9)$ \\
\hline Christian-Seventh-Day Adventist & $24(57.1)$ \\
\hline
\end{tabular}


Based on the stratified analysis, $59.5 \%$ and $40.5 \%$ were of African-American and Afro-Caribbean/Other Afro-Descent respectively, with a mean age of $59.23 \pm 11.24$ years (years $\pm S D$ ). Over fifty percent of study participants were married in contrast to $47.7 \%$ who were single, divorced, widowed, living with a partner or otherwise classified as unknown. The socioeconomic range was based on USD from $\leq \$ 2,999$ per month to $>\$ 5,000$ with educational variables split between high school/college and graduate/post graduate matriculation. Employment status was nearly equal between employed (52\%) and non-employed (48\%). The majority of the participants self-reported as belonging to some form of faith or denomination. Participants were from urban and rural communities both in the US, and the Caribbean.

Table 3 delineates the general characteristics and health related variables of the study subjects according to pre-intervention analysis. The concentration of glucose in the blood was significantly $(P<0.018)$ higher in women compared to men. However, there were no significant differences in the other parameters according to the gender of the subjects in the diagnosis of the metabolic syndrome.

Table 3

Comparison of anthropometric measurements, bioimpedance parameters, and blood lipid profiles according to genders $(\mathrm{n}=$ 42)

\begin{tabular}{|llllll|}
\hline Parameters & Male(n=4) & \multicolumn{2}{l}{ Female(n=38) } & \multirow{2}{*}{ P-value } \\
\cline { 2 - 5 } & Mean & \pm SD & Mean & \pm SD & 0.790 \\
\hline Height (in) & 67.31 & \pm 2.46 & 64.68 & \pm 2.44 & 0.235 \\
\hline Weight (lb) & 182.55 & \pm 20.28 & 193.18 & \pm 43.33 & 0.774 \\
\hline Waist (in) & 37.50 & \pm 3.89 & 38.37 & \pm 4.99 & 0.177 \\
\hline BMI & 28.77 & \pm 1.96 & 32.15 & \pm 6.44 & 0.123 \\
\hline SBP (mmHg) & 134.50 & \pm 30.23 & 130.13 & \pm 18.49 & 0.835 \\
\hline DBP (mmHg) & 80.50 & \pm 8.96 & 80.61 & \pm 11.04 & 0.700 \\
\hline Cholesterol (mg/dL) & 207.75 & \pm 23.85 & 188.61 & \pm 32.10 & 0.077 \\
\hline HDL (mg/dL) & 41.25 & \pm 6.13 & 64.63 & \pm 19.72 & 0.232 \\
\hline LDL (mg/dL) & 133.50 & \pm 14.57 & 105.08 & \pm 31.27 & 0.109 \\
\hline Triglyceride (mg/dL) & 163.50 & \pm 82.38 & 94.50 & \pm 49.37 & 0.018 \\
\hline Glucose (mg/dL) & 100.25 & \pm 10.24 & 116.42 & \pm 54.74 & \\
\hline $\begin{array}{l}\text { BMl body mass index, SBP systolic blood pressure, DBP diastolic blood pressure, HDL high density lipoprotein, LDL low } \\
\text { density lipoprotein }\end{array}$ & & & & \\
\hline - & & & & \\
\hline
\end{tabular}

Participation in the camp for two weeks improved with regard to the other parameters. Paired t-test results showed that plasma concentrations of glucose and TG were reduced post-intervention compared to pre-intervention analysis (Table 4). On the other hand, there was no significant difference in systolic blood pressure (SBP), diastolic blood pressure (DBP), waist circumference, and HDL. 
Table 4

Comparison of metabolic syndrome indicators pre and post the experiment $(n=42)$

\begin{tabular}{|c|c|c|c|c|c|c|c|}
\hline \multirow[t]{2}{*}{ Parameters } & \multicolumn{2}{|c|}{ Pre-intervention } & \multicolumn{2}{|c|}{ Post-intervention } & \multicolumn{2}{|c|}{ Delta pre-post } & \multirow[t]{2}{*}{$P$-value } \\
\hline & Mean & $\pm S D$ & Mean & $\pm S D$ & Mean & \pm SE & \\
\hline $\mathrm{SBP}(\mathrm{mmHg})$ & 130.55 & \pm 19.41 & 126.29 & \pm 16.07 & -4.26 & \pm 3.74 & 0.261 \\
\hline $\mathrm{DBP}(\mathrm{mmHg})$ & 80.60 & \pm 10.77 & 77.36 & \pm 8.51 & -3.24 & \pm 2.06 & 0.123 \\
\hline Glucose(mg/dL) & 114.88 & \pm 52.30 & 104.54 & \pm 38.90 & -10.15 & \pm 4.84 & 0.043 \\
\hline Triglyceride(mg/dL) & 101.07 & \pm 55.83 & 82.60 & \pm 32.66 & -18.48 & \pm 5.55 & 0.002 \\
\hline \multicolumn{8}{|l|}{ Waist(in) } \\
\hline Male & 37.50 & \pm 3.89 & 44.69 & \pm 11.90 & 7.19 & \pm 6.63 & 0.358 \\
\hline Female & 38.37 & \pm 4.99 & 37.19 & \pm 6.15 & -1.04 & \pm 1.23 & 0.404 \\
\hline \multicolumn{8}{|l|}{$\mathrm{HDL}(\mathrm{mg} / \mathrm{dL})$} \\
\hline Male & 41.25 & \pm 6.13 & 38.00 & \pm 5.23 & -3.25 & \pm 3.97 & 0.473 \\
\hline Female & 64.63 & \pm 19.72 & 62.24 & \pm 18.10 & -2.39 & \pm 1.56 & 0.133 \\
\hline
\end{tabular}

Table 5 shows the ratio of subjects with metabolic syndrome diagnostic risk factors pre and post retreat intervention. The beneficial effects of the program were significant based on the fact that glucose $(P<0.0001), \mathrm{TG}(P=0.024)$, and HDL levels $(P=0.0001)$ for females were significantly improved at the conclusion of the experiment compared to pre-intervention assessments. The proportion of subjects with normal fasting glucose and TG was significantly higher at the end of the program according to the metabolic syndrome index defined by the NCEP: ATP-III than prior to the intervention. However, there was no significant difference in SBP, DBP, waist circumference and HDL for males. 
Table 5

Changes in metabolic syndrome index pre and post the experiment $(n=42)$

\begin{tabular}{|c|c|c|c|c|c|}
\hline \multirow[t]{2}{*}{ Parameters } & \multicolumn{2}{|c|}{ Pre-intervention } & \multicolumn{2}{|c|}{ Post-intervention } & \multirow[t]{2}{*}{$P$-value } \\
\hline & $\mathrm{n}$ & $\%$ & $\mathbf{n}$ & $\%$ & \\
\hline SBP & & & & & 0.569 \\
\hline$\geqq 130$ & 20 & 47.62 & 17 & 40.48 & \\
\hline$<130$ & 22 & 52.38 & 25 & 59.52 & \\
\hline DBP & & & & & 0.195 \\
\hline$\geqq 85$ & 15 & 35.71 & 7 & 16.67 & \\
\hline$<85$ & 27 & 64.29 & 35 & 83.33 & \\
\hline Glucose & & & & & $<.0001$ \\
\hline$\geqq 100$ & 10 & 23.81 & 6 & 14.29 & \\
\hline$<100$ & 32 & 76.19 & 36 & 85.71 & \\
\hline Triglyceride & & & & & 0.024 \\
\hline$\geqq 150$ & 7 & 16.67 & 1 & 2.38 & \\
\hline$<150$ & 35 & 83.33 & 41 & 97.62 & \\
\hline \multicolumn{6}{|l|}{ Waist } \\
\hline Male & & & & & 0.248 \\
\hline$\geqq 40$ & 1 & 25 & 2 & 50 & \\
\hline$<40$ & 3 & 75 & 2 & 50 & \\
\hline Female & & & & & 0.858 \\
\hline$\geqq 35$ & 11 & 28.95 & 13 & 34.21 & \\
\hline$<35$ & 27 & 71.05 & 25 & 65.79 & \\
\hline \multicolumn{6}{|l|}{ HDL } \\
\hline Male & & & & & 1 \\
\hline$\geqq 40$ & 2 & 50 & 2 & 50 & \\
\hline$<40$ & 2 & 50 & 2 & 50 & \\
\hline Female & & & & & 0.0001 \\
\hline$\geqq 50$ & 10 & 26.32 & 12 & 31.58 & \\
\hline$<50$ & 28 & 73.68 & 26 & 68.42 & \\
\hline
\end{tabular}

\section{Discussion}

In addition to the natural environment and demographics, the study design included socioeconomic strata that influence health behavior outcomes. Public health research literature indicates that both socio-demographics and economics significantly impact mortality and lifestyle outcomes. In a 10-year longitudinal study it was concluded that variables such as 
employment status, income, education, occupation, race, and marital status all affected mortality [15]. The clearly demonstrated positive effects of integrated lifestyle on cardiovascular risk reduction laid the foundation for early lifestyle adoption research which focused on efficacy analysis but later trended toward implementation and increased proliferation [16]. According to comparative studies evaluating physical activity and exercise, lifestyle combined with diet normalizes glucose and regulates weight. The author postulates that "lifestyle intervention" probably has different meanings for the patient, nurse practitioner, health educator or physician and that physical activity interventions differ from the broader concept of lifestyle modification which might include smoking cessation, dietary changes, and stress reduction [16].

Emerging research is now investigating the link between faith, religion, and behavioral health. Within the African-American community, health behaviors are strongly influenced by faith [13]. The socio-demographic profile for this study group identifies $42.9 \%$ of the participants as Protestant, Catholic or otherwise unknown. Behaviors that have the potential to harm the body are usually discouraged in faith-based programs. This was also a part of the Fit 4 You Retreat study design. Faithbased principles are reflected in teachings from the pulpit and are considered appropriate within religious social groups [17].

The extensive research of Koenig et al. [18] has examined the impact and influence of culture, religion, and community perception on health behavior and lifestyle modification. This research was a quantitative peer-reviewed analysis, that evaluated data from 1872 until 2010, and it was concluded that religion and spirituality significantly impacted health and health behavioral change. Additionally, the Judeo-Christian scriptures along with other religious literature refer to the human body as a receptacle for the "Holy Spirit" (1 Corinthians 6:19-20). According to Judeo-Christian and non-Christian religions, appropriate care of the human body is held in high regard and harmful practices are condemned. These precepts and practices determine what is regarded as acceptable within the context of the various religions [18]. This faith-based paradigm is strongly emphasized throughout the Fit 4 You program to address physical as well as mental health. In this context, faith and religiosity are intricately interconnected with life, health and illness within the African-American community [19]. Amongst African-Americans health behaviors are strongly influenced by faith [13, 20]. According to comprehensive research examining the effects of religiosity and spirituality on depression conducted by Bonelli et al. [21], it was concluded that religious involvement and adherence influence decisions about health and health behaviors. The research of Bonelli et al. [21] further points out that religious scripture in other faith traditions also emphasize the person's responsibility to care for and nourish their physical body. This association between religion or spirituality and beneficial health effects have been consistent with the results observed in this two-week retreat intervention.

During the tenure of the program, consultation appointments were scheduled, and initial assessments were reviewed by an on-site medical professional. As a result of these consultations and greater personal understanding, study subjects indicated an intention to have their risk factors evaluated on a regular basis. Participants were also encouraged to take their results back to their private practitioners as a means of establishing and maintaining beneficial health behavior goals.

This research provided potentially important clinical information concerning metabolic syndrome and its prevention. These findings demonstrated a positive influence on the reduction of cardiometabolic risk factors in this high-risk population. Metabolic risks reductions were observed for all indicators with the exception of SBP, DBP and waist circumference for men. The overall findings suggest that a multi-faceted approach for lifestyle intervention may offer promising results in risk factor reduction for CVD and stroke in both men and women in this high-risk population. According to recent research by Weng et al. [22], the evidence concluded that "Elevated AST/ALT ratio is significantly associated with increased risk of developing CVD in men but not women". However, the ratio does not confer any additional benefits over established CVD risk prediction tools in the general population but may have clinical utility in certain subgroups.

Consequently, elevated liver enzyme levels may assist clinicians in detecting lifestyle related conditions resulting in nonalcoholic fatty liver disease or additional organ malfunction. The participant profiles' liver enzymes remained within normal range while serum protein levels changed slightly. This observation may be due to the dietary impact of the plant-based diet and the liver's role in detoxifying the system. Additionally, the intervention program's exercise and physical activity regimens most likely had a favorable effect. Lifestyle research reports that sustained compliance is a common issue post 
intervention. Although the scope of the study did not include these statistics, some participants reported poor compliance after returning home with regard to health behavioral change, more reported sustained change in at least two to three areas of lifestyle modification.

The Fit 4 You Lifestyle intervention program was highly effective in significantly reducing risk factors associated with metabolic syndrome. However, additional emphasis has been considered regarding mental and emotional barriers to success that challenge health behavioral change.

\section{Conclusion}

Considering the dual complexity of religion and behavioral motivation, the Fit 4 You Retreat Intervention incorporated faith as a major component for health behavior change. This study demonstrated that an integrated faith-based lifestyle approach was highly effective in significantly reducing risk factors associated with metabolic syndrome within this high-risk population. Cultural sensitivity and spirituality were strong motivators for the participants. However, future interventions should include a greater focus on mental and emotional health. Public health research reports that sustained compliance is frequently an issue with health behavioral change programs post intervention, therefore subsequent follow-up strategies should be developed that focus on implementation and sustainability.

\section{Abbreviations}

BMI

Body mass index; CVD:Cardiovascular disease; DBF:Diastolic blood pressure; Fit 4 you:Faith \& fitness, intentional improvement and time sensitive transformation for your true value, outstanding opportunities for an abundant lifestyle, and unlimited capacity; HDL-C:High-density lipoprotein cholesterol; LDL:Low density lipoprotein; NCEP:ATP III:National cholesterol education program's adult treatment panel III; SBP:Systolic blood pressure; TG:Triglyceride.

\section{Declarations}

\section{Acknowledgements}

Not applicable.

\section{Authors' contributions}

RRD, EAR, ALS, and K-SH conceived and designed the study. RRD, H-JH, T-HJ, and K-SH wrote the manuscript with input from all other members. JYC performed statistical analysis of data. HP-S analyzed the results. All authors read and approved the final manuscript.

\section{Funding}

Not applicable.

\section{Availability of data and materials}

The datasets used and/or analyzed during the current study are available from the corresponding author on reasonable request.

\section{Ethics approval and consent to participate}

This study was approved by Sahmyook University's institutional review board (SYUIRB\# 2011-015) and conducted during the two-week summer session of the Fit 4 You Retreat, July 8-22, 2012.

Page $11 / 13$ 


\section{Consent for publication}

Not applicable.

\section{Competing interests}

The authors declared no potential conflicts of interest with relation to the research, authorship and publication of this paper.

\section{References}

1. 1. King H, Aubert RE, Herman, WH. Global burden of diabetes, 1995-2025: prevalence, numerical estimates, and projections. Diabetes Care. 1998;21:1414-31.

2. 2. Yamaoka $\mathrm{K}$, Tango T. Effects of lifestyle modification on metabolic syndrome: a systematic review and metaanalysis. BMC. Med 2012;10:138.

3. 3. Huang PL. A comprehensive definition for metabolic syndrome. Dis Model Mech. 2009;2:231 - 37.

4. 4. Zimmet P, Alberti KGMM, Shaw J. Global and societal implications of the diabetes epidemic. Nature. 2001;414:782 87.

5. 5. Artinian NT, Fletcher GF, Mozaffarian D, Kris-Etherton P, Van Horn L, Lichtenstein A H, et al. Interventions to promote physical activity and dietary lifestyle changes for cardiovascular risk factor reduction in adults: A scientific statement from the American heart association. Circulation. 2010;122:406 - 41.

6. 6. Eckel RH, Grundy SM, Zimmet PZ. The metabolic syndrome. Lancet. 2005;365:1415-28.

7. 7. Hanson RL, Imperatore G, Bennett PH, Knowler WC. Components of the "metabolic syndrome" and incidence of type 2 diabetes. Diabetes. 2002;51:3120-27.

8. 8. Expert Panel on Detection, Evaluation, and Treatment of High Blood Cholesterol in Adults. Executive summary of the third report of the National Cholesterol Education Program (NCEP) expert panel on detection, evaluation, and treatment of high blood cholesterol in adults (Adult Treatment Panel III). Jama. 2001;285:2486-97.

9. 9. Grundy SM, Hansen B, Smith SC Jr, Cleeman JI, Kahn RA. Clinical management of metabolic syndrome: report of the American Heart Association/National Heart, Lung, and Blood Institute/American Diabetes Association conference on scientific issues related to management. Arterioscler Thromb Vasc Biol. 2004;109:551 - 56.

10. 10. Grundy SM, Abate N, Chandalia M. Diet composition and the metabolic syndrome: what is the optimal fat intake. Am J Med. 2002;113:25-29.

11. 11. Klein S, Sheard NF, Pi-Sunyer X, Daly A, Wylie-Rosett J, Kulkarni K, et al. Weight management through lifestyle modification for the prevention and management of type 2 diabetes: rationale and strategies: a statement of the American Diabetes Association, the North American Association for the Study of Obesity, and the American Society for Clinical Nutrition. Am J Clin Nutr. 2004;80:257 - 63.

12. 12. Pool LR, Ning H, Lloyd-Jones DM, Allen NB. Trends in racial/ethnic disparities in cardiovascular health among US adults from 1999-2012. J Am Heart Assoc. 2017;doi: 10.1161/JAHA.117.006027.

13. 13. Bopp M, Lattimore D, Wilcox S, Laken M, McClorin L, Swinton R, et al. Understanding physical activity participation in members of an African American church: a qualitative study. Health Educ Res. 2007;22:815 - 26.

14. 14. Dodani S, Kramer MK, Williams L, Crawford S, Kriska A. Fit body and soul: a church-based behavioral lifestyle program for diabetes prevention in African Americans. Ethn Dis. 2009;19:135 - 41.

15. 15. Sorlie PD, Backlund E, Keller JB. US mortality by economic, demographic, and social characteristics: the National Longitudinal Mortality Study. Am J Public Health. 1995;85:949 - 56.

16. 16. Dunn AL. The effectiveness of lifestyle physical activity interventions to reduce cardiovascular disease. Am J Lifestyle Med. 2009;3:11-18. 
17. 17. Holt CL, Schulz E, Wynn TA. Perceptions of the religion-health connection among African Americans in the southeastern United States: Sex, age, and urban/rural differences. Health Educ Behav. 2009;36:62-80.

18. 18. Koenig HG, Zaben FA, Khalifa DA. Religion, spirituality and mental health in the West and the Middle East. Asian J Psychiatr. 2012;5:180 - 82.

19. 19. Spruill IJ, Magwood GS, Nemeth LS, Williams TH. African Americans' gulturally specific approaches to the management of diabetes. Glob Qual Nurs Res. 2015;doi: 10.1177/2333393614565183.

20. 20. Gallagher NA, Gretebeck KA, Robinson JC, Torres ER, Murphy SL, Martyn KK. Neighborhood factors relevant for walking in older, urban, African American adults. J Aging Phys Act. 2010;18:99-115.

21. 21. Bonelli R, Dew RE, Koenig HG, Rosmarin DH, Vasegh S. Religious and spiritual factors in depression: review and integration of the research. Depress Res Treat. 2012;doi: 10.1155/2012/962860.

22. 22. Weng SF, Kai J, Guha IN, Qureshi N. The value of aspartate aminotransferase and alanine aminotransferase in cardiovascular disease risk assessment. Open Heart. 2015;doi: 10.1136/openhrt-2015-000272. 